\title{
Staphylococcal Infections: Host and Pathogenic Factors
}

\author{
Rajan P. Adhikari
}

Integrated Biotherapeutics Inc., Rockville, MD 20878, USA; rajan@IntegratedBiotherapeutics.com

Citation: Adhikari, R.P.

Staphylococcal Infections: Host and Pathogenic Factors. Microorganisms 2021, 9, 1080. https://doi.org/ $10.3390 /$ microorganisms 9051080

Received: 20 April 2021

Accepted: 21 April 2021

Published: 18 May 2021

Publisher's Note: MDPI stays neutral with regard to jurisdictional claims in published maps and institutional affiliations.

Copyright: (C) 2021 by the author. Licensee MDPI, Basel, Switzerland. This article is an open access article distributed under the terms and conditions of the Creative Commons Attribution (CC BY) license (https:/ / creativecommons.org/licenses/by/ $4.0 /)$.
In 1880, the Scottish surgeon Sir Alexander Ogston first described staphylococci in pus from a surgical abscess in a knee joint: "The masses looked like bunches of grapes" [1]. In 1884, the German physician Friedrich Julius Rosenbach differentiated the staphylococci by the color of their colonies: S. aureus (from the Latin aurum, gold) [2]. For another 20 years, very little was known on the pathophysiology of this bug. Based on a PubMed search record, the first Staphylococcal paper was published in 1900 on a case report [3]. More and more scientists gradually engaged to study diseases caused by this bacterium. There were some 10 publications recorded during the period 1900-1910, which translate in average to one publication/year. Research on this bug exploded in the 20th century, which is reflected in a recent PubMed search. It yields 47,974 publications records when searched using the keyword "Staphylococcus" in the title. During the period 2010-2020, the average publication was 2000 articles/year. This record makes Staphylococcus the single most researched bacterium based on this publication track record.

Over time, numerous Staphylococcus species were discovered, consisting of more than 45 staphylococcal species and 24 subspecies classified using molecular methods [4]. These various species of Staphylococcus are clinically important as 30\% of the healthy human population is colonized with various Staphylococcus spp. Some strains are opportunistic pathogens and can cause a minor infection to life-threatening diseases. Pathogenicity of these different strains depends on several virulence factors: Level of protein expression as well as the robustness of the regulatory networks expressing these virulence factors. These factors consist of numerous toxins, enterotoxins (some of which act as superantigens), enzymes, and proteins with other functions (cytoplasmic, extracellular, and surface) that are tightly regulated by two-components (TC), transcriptional and translational regulators, as well as quorum-sensing (QS) regulatory networks [5]. This Special Issue is dedicated to the studies and recent advancements in our understanding of staphylococcal virulence mechanisms that enable Staphylococcus spp. either to successfully establish themselves as a colonizer or to overcome the host's defense system to cause infection.

Fourteen wonderful papers are included in this issue with a wide spectrum of Staphylococcal research. A vaccine paper by Dr. Anderson from the Pfizer Vaccine group entitled "Performance of a four-Antigen S. aureus vaccine in preclinical models of Invasive diseases [6]" clearly reflects a critical problem faced by all vaccine companies struggling to demonstrate that these vaccines are clinically efficacious so that they can be approved by regulatory agencies: A lack of correlation between preclinical efficacies with human clinical trials [6]. The SA4Ag vaccine described in this paper clearly demonstrates the significant decrease in the organ bacterial loads in a deep tissue infection, a bacteremia, a pyelonephritis mouse model, as well as a complete protection of endocarditis in a rat model, which is still not enough to provide significant protection in human surgery-associated invasive $S$. aureus infection.

This is not a single case. Most of the anti-staphylococcal vaccine and therapeutics that failed in clinical trials 2 and 3 have similar stories. Merck V710, an S. aureus iron-regulated surface determinant $\mathrm{B}$ (IsdB) vaccine, provided a significant protection in different animal models (both by active and passive immunization) [7-11], whereas it failed in a blinded randomized trial [12]. Anti-toxin engineered $\mathrm{mAb}$ successfully neutralized six major $S$. aureus toxins in an in vitro study, as well as exhibited great efficacies in various animal 
models [13-16], but failed in a human clinical trial (https: / / clinicaltrials.gov/ct2/show / NCT02940626 (accessed on 19 April 2021)) due to the lack of enough efficacy. In recent years, these failed efficacy studies sparked a clear debate among the Staphylococcal vaccinologists and therapeutic scientists into two schools of thought: One believes in surface protein and other believes in extracellular toxins and proteins as better targets. A great review by Millar et al. [17] has published evidence that extracellular toxins such as pore-forming toxins (PFT) and superantigens targeted therapeutics/vaccine are more likely to provide better protection over the approaches to induce antibodies to facilitate opsonophagocytosis [17] Numerous recent published papers focused on targeting secreted toxins and virulence factors [18-23] as vaccine targets. Again, in animal models, great protection and efficacy were reported in this approach. On the other side, many scientists believe that the surface proteins, capsule, and cell wall structure such as the Wall teichoic acid (WTA) [24-28] and lipoteichoic acid (LTA) are better targets which are well characterized. In addition, the important virulence factors helping bacterial adhesion and invasions are an important target for future vaccine and therapeutics development. Equally convincing data are available to support this hypothesis (in different animal models) [11,29-33]. Not only the vaccine, but also different therapeutics options for anti-staphylococcal infections failed to provide enough protection in the human clinical trial even though their preclinical data in animal models were impressive $[12,13,28]$. I completely agree and hope that all the scientists working in these areas agree with the author [6], in that a clear animal efficacy model is needed for every intended vaccine and therapeutic testing, which correlates with the human clinical outcome before going into these expensive clinical trials to save resources, human subjects, as well as time.

A paper by Dr. Holtfreter, "Discovery of S. aureus Adhesion Inhibitors by Automated Imaging and Their Characterization in a Mouse Model of Persistent Nasal Colonization" describes a novel automated high throughput screening method that can quantify the bacterial adhesion in human epithelial cells [34]. Since adhesion inhibitors/blockers/neutralizers interfere with the entry of pathogens into the cell, it will be a highly effective treatment for the first line of defense [35-38]. Many studies have generated high-quality data in favor of arresting pathogens in these stages [39-44].

A paper by Dr. Bischoff's group from Saarland University explained the role of histidine-containing phosphocarrier protein HPr (encoded by $\mathrm{ptsH}$ ) in carbon catabolite repression (CCR) and infectivity [45]. CCR has been established as a connector for metabolome to the virulence factors [46-53]. Though the impact of HPr on CCR is well studies in other Gram positive bacteria, it was largely unknown in S. aureus This paper clearly demonstrates that the inactivation of $p t s H$ alters the transcription of genes involved in the TCA cycle as well as alpha hemolysin, a well-characterized virulence factor in S.aureus. A significant reduction in biofilm production was reported in the $p t s H$ mutant under static and flow conditions, which correlates in a reduction in CFU/catheter fragment in a S. aureus-based murine foreign body infection model. Putting these data together, there is a clear potential of $p t s H$ to be a target gene for vaccine and therapeutics. srtA is an another gene function reported in this Special Issue by Dr. Becker's group [54]. Though well characterized in S. aureus [55-59], very little is known about the role of this gene in another species: S. lugdunensis. This paper demonstrates that though there is no significant decrease in adherence and invasion in a human cell line, the mutant srtA exhibited a decrease in biofilm production, as well as affected the transcription of two different adhesins genes $(\mathrm{Fbl}$ and $\mathrm{vWbF})$. Since srt $\mathrm{A}$ in different pathogens is considered as a therapeutic target $[60,61]$, the characterization of this locus in new species is critical to understanding the pathogen.

Two papers included in this issue are focused on the characterization of S. aureus biofilm inhibitors. Dr. Reigada reported the "Combined Effect of Naturally-Derived Biofilm Inhibitors and Differentiated HL-60 Cells in the Prevention of S. aureus Biofilm Formation" [62] and the other by Dr. Jimi from Fukuoka University on "The Effects of Silver Sulfadiazine on Methicillin-Resistant S. aureus Biofilms" [63]. Staphylococcal biofilm 
is still a huge health burden throughout the world as $80 \%$ of the infection in medical device associated infection (usually hospital acquired) results in biofilm. In the former paper [62], three naturally derived biofilm inhibitors: Dehydroabietic acid (DHA) 1 and 2 and the third one flavan derivative (FLA1) were tested along with differentiated HL-60 cells in implantable titanium devices and low-density polyethylene endotracheal tubes. Out of the three tested inhibitors, DHA1 exhibited the optimal anti-biofilm profile in coculture. These compounds can have a great potential for anti-biofilm drugs in medical devices. In a later paper [63], anti-biofilm activities of the existing drug silver sulfadiazine is reported.

Dr. Månsson in her paper "Methicillin-Resistant S. epidermidis (MRSE) Lineages in the Nasal and Skin Microbiota of Patients Planned for Arthroplasty Surgery" [64] reports a clinical study where $45 \%$ of patients were colonized with MRSE, among them $15 \%$ were with multidrug-resistant strains. A previously reported lineage associated with prosthetic joint infections was among the isolates. This type of screening prior to hospitalization and proper antimicrobial prophylaxis helps minimize cross infections. Dr. Dekker reported the molecular characterization of the $S$. aureus isolates from chronically infected wounds in rural Ghana [65]. Twenty-eight isolates were characterized by whole genome sequencing and the resistance profile was analyzed to determine the population structure of the isolates in the rural part.

The bacterial strain-specific model development in different animals is very critical for efficacy testing of the vaccine, therapeutics, as well as an antimicrobial development pipeline. An epidemiological study for the predominant clones and animal model development based on these existing clones are vital for the success of any drug and biologics. In a very elaborate study, Dr. Zhang compares "Community-Associated MRSA Strain USA300 from Other MRSA Strains in A Murine Skin Infection Model" [66]. In a dermatopathology readout, USA300 induced dermonecrosis with extensive open [67] lesions, increased neutrophil recruitment, and increased the production of cytokines associated with disease severity when compared with USA400 and M92 (colonizing control) strains. This study is highly relevant as USA300 is still one of the leading causes of community and hospitalacquired infections in the USA, as well as many countries around the world [68-73].

A paper by Dr. Ehrhardt's group from Jena University reported a significant impact on the regulation of pro-inflammatory factors contributing to a synergistic effect on cells' intrinsic innate response when a human $S$. aureus small colony variants colonizer is subsequently infected with influenza virus [74].

Dr. Johler's group from the University of Zurich reported the possibility of posttranscriptional modifications in SEC expression under lactic acid stress conditions, in some strains of S. aureus, based on the difference in the level of sec mRNA with protein [75]. Since enterotoxins are a major cause of staphylococcal food poisoning in humans [76,77], the $\mathrm{pH}$-dependent regulations (transcription and translations) of these genes under different food storage conditions are of interest in terms of food safety as well as food shelf life.

A paper by Dr. Mishra, Dr. Bayer, and Dr. Rose's group from UCLA on "Cell Membrane Adaptations Mediate $\beta$-Lactam-Induced Resensitization of Daptomycin-Resistant (DAP-R) Staphylococcus aureus In Vitro" reported the multiple mechanisms involving the resensitization of DAP-R back to sensitive strains by prolonged exposure to cloxacillin [78]. The reported mechanisms involved the accumulation of multiple point mutations in the $m p r F$ gene, resulting in overall changes in cell membrane composition and function [79]. This study is highly significant during the era in which most antibiotics are ineffective due to the emergence of drug resistance and a very limited discovery pipeline because of its high cost. Understanding these resistance mechanisms will help to repurpose these old drugs which are relatively cost-effective [80-82].

There are two review papers included in this issue. One is "Human mecC-Carrying MRSA: Clinical Implications and Risk Factors" [83]. This relatively new mecC type first reported in 2011 has now been reported in animals as well as in humans. This review covers epidemiological data for mecC carrying MRSA strains including the resistance profile, and virulence factors associated with different clonal complexes. Another is, "No Change, No 
Life? What We Know about Phase Variation in Staphylococcus aureus" [84] by Dr. Gor. In this review based on the relatively new topic, the author discusses a different aspect of gene switching and phase variation in S. aureus. Since, heterogeneity and phase variations are common phenomena in $S$. aureus $[85,86]$ and can be clearly visible in terms of an antibiotic heterogeneous population, small colony variants, and persister colonies [74,87-92], this review shed the light on the possible mechanism of these genes switching.

Overall, this issue has an impressive participation of scientists throughout the world. We would like to thank all the authors, contributors, and reviewers for their valuable time and their important contribution to this Special Issue.

Funding: The APC was funded by AI136143 from National Institute of Allergey and Infectious Diseases.

Conflicts of Interest: This article is an opinion of the author and does not reflect the company's interest.

\section{References}

1. Classics in infectious diseases. On abscesses. Alexander Ogston (1844-1929). Rev. Infect. Dis. 1984, 6, 122-128.

2. Rosenbach, A. Mikro-Qrganismen bei den Wund-Infections-Krankheiten desMenschen; Wiesbaden, J.F., Ed.; Bergmann: Wiesbaden, Germany, 1884; p. 18.

3. Berg, A.A., VI. A Case of Acute Osteomyelitis of the Femur, with General Systemic Staphylococcus aureus Infection, Terminating in Recovery. Ann. Surg. 1900, 31, 332-339. [CrossRef] [PubMed]

4. GiovanniGherardi, G.B. VincenzoSavini, Staphylococcal Taxonomy; Academic Press: Cambridge, MA, USA, 2018 ; Volume 1.

5. Novick, R.P. Autoinduction and signal transduction in the regulation of staphylococcal virulence. Mol. Microbiol. 2003, 48, 1429-1449. [CrossRef]

6. Scully, I.L.; Timofeyeva, Y.; Illenberger, A.; Lu, P.; Liberator, P.A.; Jansen, K.U.; Anderson, A.S. Performance of a Four-Antigen Staphylococcus aureus Vaccine in Preclinical Models of Invasive S. aureus Disease. Microorganisms 2021, 9, 177. [CrossRef] [PubMed]

7. Joshi, A.; Pancari, G.; Cope, L.; Bowman, E.P.; Cua, D.; Proctor, R.A.; McNeely, T. Immunization with Staphylococcus aureus iron regulated surface determinant B (IsdB) confers protection via Th17/IL17 pathway in a murine sepsis model. Hum. Vaccin. Immunother. 2012, 8, 336-346. [CrossRef] [PubMed]

8. Ebert, T.; Smith, S.; Pancari, G.; Clark, D.; Hampton, R.; Secore, S.; Towne, V.; Fan, H.; Wang, X.; Wu, X.; et al. A fully human monoclonal antibody to Staphylococcus aureus iron regulated surface determinant B (IsdB) with functional activity in vitro and in vivo. Hum. Antibodies 2010, 19, 113-128. [CrossRef] [PubMed]

9. Brown, M.; Kowalski, R.; Zorman, J.; Wang, X.; Towne, V.; Zhao, Q.; Secore, S.; Finnefrock, A.C.; Ebert, T.; Pancari, G.; et al. Selection and characterization of murine monoclonal antibodies to Staphylococcus aureus iron-regulated surface determinant $\mathrm{B}$ with functional activity in vitro and in vivo. Clin. Vaccine Immunol. 2009, 16, 1095-1104. [CrossRef]

10. Raedler, M.D.; Heyne, S.; Wagner, E.; Shalkowski, S.K.; Secore, S.; Anderson, A.S.; Cook, J.; Cope, L.; McNeely, T.; Retzlaff, M.; et al. Serologic assay to quantify human immunoglobulin $\mathrm{G}$ antibodies to the Staphylococcus aureus iron surface determinant B antigen. Clin. Vaccine Immunol. 2009, 16, 739-748. [CrossRef]

11. Kuklin, N.A.; Clark, D.J.; Secore, S.; Cook, J.; Cope, L.D.; McNeely, T.; Noble, L.; Brown, M.J.; Zorman, J.K.; Wang, X.M.; et al. A novel Staphylococcus aureus vaccine: Iron surface determinant B induces rapid antibody responses in rhesus macaques and specific increased survival in a murine S. aureus sepsis model. Infect. Immun. 2006, 74, 2215-2223. [CrossRef]

12. McNeely, T.B.; Shah, N.A.; Fridman, A.; Joshi, A.; Hartzel, J.S.; Keshari, R.S.; Lupu, F.; DiNubile, M.J. Mortality among recipients of the Merck V710 Staphylococcus aureus vaccine after postoperative S. aureus infections: An analysis of possible contributing host factors. Hum. Vaccin. Immunother. 2014, 10, 3513-3516. [CrossRef]

13. Stulik, L.; Rouha, H.; Labrousse, D.; Visram, Z.C.; Badarau, A.; Maierhofer, B.; Gross, K.; Weber, S.; Kramaric, M.D.; Glojnaric, I.; et al. Preventing lung pathology and mortality in rabbit Staphylococcus aureus pneumonia models with cytotoxin-neutralizing monoclonal IgGs penetrating the epithelial lining fluid. Sci. Rep. 2019, 9, 5339. [CrossRef] [PubMed]

14. Rouha, H.; Weber, S.; Janesch, P.; Maierhofer, B.; Gross, K.; Dolezilkova, I.; Mirkina, I.; Visram, Z.C.; Malafa, S.; Stulik, L.; et al. Disarming Staphylococcus aureus from destroying human cells by simultaneously neutralizing six cytotoxins with two human monoclonal antibodies. Virulence 2018, 9, 231-247. [CrossRef] [PubMed]

15. Rouha, H.; Badarau, A.; Visram, Z.C.; Battles, M.B.; Prinz, B.; Magyarics, Z.; Nagy, G.; Mirkina, I.; Stulik, L.; Zerbs, M.; et al. Five birds, one stone: Neutralization of alpha-hemolysin and 4 bi-component leukocidins of Staphylococcus aureus with a single human monoclonal antibody. MAbs 2015, 7, 243-254. [CrossRef] [PubMed]

16. Diep, B.A.; Le, V.T.M.; Visram, Z.C.; Rouha, H.; Stulik, L.; Dip, E.C.; Nagy, G.; Nagy, E. Improved Protection in a Rabbit Model of Community-Associated Methicillin-Resistant Staphylococcus aureus Necrotizing Pneumonia upon Neutralization of Leukocidins in Addition to Alpha-Hemolysin. Antimicrob. Agents Chemother. 2016, 60, 6333-6340. [CrossRef] 
17. Miller, L.S.; Fowler, V.G., Jr.; Shukla, S.K.; Rose, W.E.; Proctor, R.A. Development of a vaccine against Staphylococcus aureus invasive infections: Evidence based on human immunity, genetics and bacterial evasion mechanisms. FEMS Microbiol. Rev. 2020, 44, 123-153. [CrossRef]

18. Adhikari, R.P.; Karauzum, H.; Sarwar, J.; Abaandou, L.; Mahmoudieh, M.; Boroun, A.R.; Vu, H.; Nguyen, T.; Devi, V.S.; Shulenin, S.; et al. Novel structurally designed vaccine for $S$. aureus alpha-hemolysin: Protection against bacteremia and pneumonia. PLoS ONE 2012, 7, e38567. [CrossRef]

19. Adhikari, R.P.; Kort, T.; Shulenin, S.; Kanipakala, T.; Ganjbaksh, N.; Roghmann, M.; Holtsberg, F.W.; Aman, M.J. Antibodies to S. aureus LukS-PV Attenuated Subunit Vaccine Neutralize a Broad Spectrum of Canonical and Non-Canonical Bicomponent Leukotoxin Pairs. PLoS ONE 2015, 10, e0137874. [CrossRef] [PubMed]

20. Adhikari, R.P.; Thompson, C.D.; Aman, M.J.; Lee, J.C. Protective efficacy of a novel alpha hemolysin subunit vaccine (AT62) against Staphylococcus aureus skin and soft tissue infections. Vaccine 2016, 34, 6402-6407. [CrossRef]

21. Kailasan, S.; Kort, T.; Mukherjee, I.; Liao, G.C.; Kanipakala, T.; Williston, N.; Ganjbaksh, N.; Venkatasubramaniam, A.; Holtsberg, F.W.; Karauzum, H.; et al. Rational Design of Toxoid Vaccine Candidates for Staphylococcus aureus Leukocidin AB (LukAB). Toxins 2019, 11, 339. [CrossRef] [PubMed]

22. Karauzum, H.; Venkatasubramaniam, A.; Adhikari, R.P.; Kort, T.; Holtsberg, F.W.; Mukherjee, I.; Mednikov, M.; Ortines, R.; Nguyen, N.T.Q.; Doan, T.; et al. IBT-V02: A Multicomponent Toxoid Vaccine Protects Against Primary and Secondary Skin Infections Caused by Staphylococcus aureus. Front. Immunol. 2021, 12, 624310. [CrossRef]

23. Venkatasubramaniam, A.; Liao, G.; Cho, E.; Adhikari, R.P.; Kort, T.; Holtsberg, F.W.; Elsass, K.E.; Kobs, D.J.; Rudge, T.L., Jr.; Kauffman, K.D.; et al. Safety and Immunogenicity of a 4-Component Toxoid-Based Staphylococcus aureus Vaccine in Rhesus Macaques. Front. Immunol. 2021, 12, 621754. [CrossRef]

24. Van Dalen, R.; Molendijk, M.M.; Ali, S.; van Kessel, K.P.M.; Aerts, P.; van Strijp, J.A.G.; de Haas, C.J.C.; Codee, J.; van Sorge, N.M. Do not discard Staphylococcus aureus WTA as a vaccine antigen. Nature 2019, 572, E1-E2. [CrossRef]

25. Fattom, A.I.; Sarwar, J.; Ortiz, A.; Naso, R. A Staphylococcus aureus capsular polysaccharide (CP) vaccine and CP-specific antibodies protect mice against bacterial challenge. Infect. Immun. 1996, 64, 1659-1665. [CrossRef] [PubMed]

26. O'Brien, F.G. Staphylococcus aureus vaccine conjugate-Nabi: Nabi-StaphVAX, StaphVAX. Drugs R. D. $2003,4,383-385$.

27. Fattom, A.; Fuller, S.; Propst, M.; Winston, S.; Muenz, L.; He, D.; Naso, R.; Horwith, G. Safety and immunogenicity of a booster dose of Staphylococcus aureus types 5 and 8 capsular polysaccharide conjugate vaccine (StaphVAX) in hemodialysis patients. Vaccine 2004, 23, 656-663. [CrossRef]

28. Fattom, A.I.; Horwith, G.; Fuller, S.; Propst, M.; Naso, R. Development of StaphVAX, a polysaccharide conjugate vaccine against S. aureus infection: From the lab bench to phase III clinical trials. Vaccine 2004, 22, 880-887. [CrossRef] [PubMed]

29. Begier, E.; Seiden, D.J.; Patton, M.; Zito, E.; Severs, J.; Cooper, D.; Eiden, J.; Gruber, W.C.; Jansen, K.U.; Anderson, A.S.; et al. SA4Ag, a 4-antigen Staphylococcus aureus vaccine, rapidly induces high levels of bacteria-killing antibodies. Vaccine 2017, 35, 1132-1139. [CrossRef] [PubMed]

30. Schneewind, O.; Missiakas, D. Sortases, Surface Proteins, and Their Roles in Staphylococcus aureus Disease and Vaccine Development. Microbiol. Spectr. 2019, 7.

31. Zhang, F.; Jun, M.; Ledue, O.; Herd, M.; Malley, R.; Lu, Y. Antibody-mediated protection against Staphylococcus aureus dermonecrosis and sepsis by a whole cell vaccine. Vaccine 2017, 35, 3834-3843. [CrossRef]

32. Stranger-Jones, Y.K.; Bae, T.; Schneewind, O. Vaccine assembly from surface proteins of Staphylococcus aureus. Proc. Natl. Acad. Sci. USA 2006, 103, 16942-16947. [CrossRef]

33. Yu, W.; Yao, D.; Yu, S.; Wang, X.; Li, X.; Wang, M.; Liu, S.; Feng, Z.; Chen, X.; Li, W.; et al. Protective humoral and CD4(+) T cellular immune responses of Staphylococcus aureus vaccine MntC in a murine peritonitis model. Sci. Rep. 2018, 8, 3580. [CrossRef] [PubMed]

34. Fernandes de Oliveira, L.M.; Steindorff, M.; Darisipudi, M.N.; Mrochen, D.M.; Trube, P.; Broker, B.M.; Bronstrup, M.; Tegge, W.; Holtfreter, S. Discovery of Staphylococcus aureus Adhesion Inhibitors by Automated Imaging and Their Characterization in a Mouse Model of Persistent Nasal Colonization. Microorganisms 2021, 9, 631. [CrossRef]

35. Mu, D.; Xiang, H.; Dong, H.; Wang, D.; Wang, T. Isovitexin, a Potential Candidate Inhibitor of Sortase A of Staphylococcus aureus USA300. J. Microbiol. Biotechnol. 2018, 28, 1426-1432. [CrossRef] [PubMed]

36. Wang, G.; Wang, X.; Sun, L.; Gao, Y.; Niu, X.; Wang, H. Novel Inhibitor Discovery of Staphylococcus aureus Sortase B and the Mechanism Confirmation via Molecular Modeling. Molecules 2018, 23, 977. [CrossRef] [PubMed]

37. Hogan, S.; Kasotakis, E.; Maher, S.; Cavanagh, B.; O'Gara, J.P.; Pandit, A.; Keyes, T.E.; Devocelle, M.; O’Neill, E. A novel medical device coating prevents Staphylococcus aureus biofilm formation on medical device surfaces. FEMS Microbiol. Lett. 2019, 366, fnz107. [CrossRef] [PubMed]

38. Elshina, E.; Allen, E.R.; Flaxman, A.; van Diemen, P.M.; Milicic, A.; Rollier, C.S.; Yamaguchi, Y.; Wyllie, D.H. Vaccination with the Staphylococcus aureus secreted proteins EapH1 and EapH2 impacts both S. aureus carriage and invasive disease. Vaccine 2019, 37, 502-509. [CrossRef] [PubMed]

39. Li, T.; Huang, M.; Song, Z.; Zhang, H.; Chen, C. Biological characteristics and conjugated antigens of ClfA A-FnBPA and CP5 in Staphylococcus aureus. Can. J. Vet. Res. 2018, 82, 48-54.

40. Liu, Y.; Sul, Y.; Zhang, B.; Su, L.; Jiang, H. Immunological comparison of Efb and ClfA of Staphylococcus aureus isolated from bovine. Sheng Wu Gong Cheng Xue Bao 2015, 31, 1335-1343. 
41. Delfani, S.; Mobarez, A.M.; Fooladi, A.A.I.; Amani, J.; Emaneini, M. Protection of mice against Staphylococcus aureus infection by a recombinant protein ClfA-IsdB-Hlg as a vaccine candidate. Med. Microbiol. Immunol. 2016, 205, 47-55. [CrossRef]

42. Veloso, T.R.; Mancini, S.; Giddey, M.; Vouillamoz, J.; Que, Y.; Moreillon, P.; Entenza, J.M. Vaccination against Staphylococcus aureus experimental endocarditis using recombinant Lactococcus lactis expressing ClfA or FnbpA. Vaccine 2015, 33, $3512-3517$. [CrossRef]

43. Li, Y.; Li, Z.; Ye, J. Identification of Th cell epitopes on clfA adhesin of Staphylococcus aureus and characterization of their role in immunity. Wei Sheng Wu Xue Bao 2013, 53, 966-975.

44. Brouillette, E.; Lacasse, P.; Shkreta, L.; Belanger, J.; Grondin, G.; Diarra, M.S.; Fournier, S.; Talbot, B.G. DNA immunization against the clumping factor A (ClfA) of Staphylococcus aureus. Vaccine 2002, 20, 2348-2357. [CrossRef]

45. Patzold, L.; Brausch, A.; Bielefeld, E.; Zimmer, L.; Somerville, G.A.; Bischoff, M.; Gaupp, R. Impact of the Histidine-Containing Phosphocarrier Protein HPr on Carbon Metabolism and Virulence in Staphylococcus aureus. Microorganisms 2021, 9, 466. [CrossRef] [PubMed]

46. Crooke, A.K.; Fuller, J.R.; Obrist, M.W.; Tomkovich, S.E.; Vitko, N.P.; Richardson, A.R. CcpA-independent glucose regulation of lactate dehydrogenase 1 in Staphylococcus aureus. PLoS ONE 2013, 8, e54293. [CrossRef] [PubMed]

47. Nuxoll, A.S.; Fuller, J.R.; Obrist, M.W.; Tomkovich, S.E.; Vitko, N.P.; Richardson, A.R. CcpA regulates arginine biosynthesis in Staphylococcus aureus through repression of proline catabolism. PLoS Pathog 2012, 8, e1003033. [CrossRef]

48. Leiba, J.; Hartmann, T.; Cluzel, M.; Cohen-Gonsaud, M.; Delolme, F.; Bischoff, M.; Molle, V. A novel mode of regulation of the Staphylococcus aureus catabolite control protein A (CcpA) mediated by Stk1 protein phosphorylation. J. Biol. Chem. 2012, 287, 43607-43619. [CrossRef]

49. Li, C.; Sun, F.; Cho, H.; Yelavarthi, V.; Sohn, C.; He, C.; Schneewind, O.; Bae, T. CcpA mediates proline auxotrophy and is required for Staphylococcus aureus pathogenesis. J. Bacteriol. 2010, 192, 3883-3892. [CrossRef]

50. Seidl, K.; Muller, S.; Franccois, P.; Kriebitzsch, C.; Schrenzel, J.; Engelmann, S.; Bischoff, M.; Berger-Bachi, B. Effect of a glucose impulse on the CcpA regulon in Staphylococcus aureus. BMC Microbiol. 2009, 9, 95. [CrossRef]

51. Seidl, K.; Bischoff, M.; Berger-Bachi, B. CcpA mediates the catabolite repression of tst in Staphylococcus aureus. Infect. Immun. 2008, 76, 5093-5099. [CrossRef]

52. Seidl, K.; Goerke, C.; Wolz, C.; Mack, D.; Berger-Bachi, B.; Bischoff, M. Staphylococcus aureus CcpA affects biofilm formation. Infect. Immun. 2008, 76, 2044-2050. [CrossRef]

53. Seidl, K.; Stucki, M.; Ruegg, M.; Goerke, C.; Wolz, C.; Harris, L.; Berger-Bachi, B.; Bischoff, M. Staphylococcus aureus CcpA affects virulence determinant production and antibiotic resistance. Antimicrob. Agents Chemother. 2006, 50, 1183-1194. [CrossRef]

54. Hussain, M.; Kohler, C.; Becker, K. Role of SrtA in Pathogenicity of Staphylococcus lugdunensis. Microorganisms 2020, 8, 1975. [CrossRef]

55. Frankel, B.A.; Bentley, M.; Kruger, R.G.; McCafferty, D.G. Vinyl sulfones: Inhibitors of SrtA, a transpeptidase required for cell wall protein anchoring and virulence in Staphylococcus aureus. J. Am. Chem. Soc. 2004, 126, 3404-3405. [CrossRef] [PubMed]

56. Kruger, R.G.; Dostal, P.; McCafferty, D.G. Development of a high-performance liquid chromatography assay and revision of kinetic parameters for the Staphylococcus aureus sortase transpeptidase SrtA. Anal. Biochem. 2004, 326, 42-48. [CrossRef]

57. Kruger, R.G.; Otvos, B.; Frankel, B.A.; Bentley, M.; Dostal, P.; McCafferty, D.G. Analysis of the substrate specificity of the Staphylococcus aureus sortase transpeptidase SrtA. Biochemistry. 2004, 43, 1541-1551. [CrossRef] [PubMed]

58. Weiss, W.J.; Lenoy, E.; Murphy, T.; Tardio, L.; Burgio, P.; Projan, S.J.; Schneewind, O.; Alksne, L. Effect of srtA and srtB gene expression on the virulence of Staphylococcus aureus in animal models of infection. J. Antimicrob. Chemother. 2004, 53, 480-486. [CrossRef] [PubMed]

59. Huang, X.; Aulabaugh, A.; Ding, W.; Kapoor, B.; Alksne, L.; Tabei, K.; Ellestad, G. Kinetic mechanism of Staphylococcus aureus sortase SrtA. Biochemistry 2003, 42, 11307-11315. [CrossRef]

60. Yang, T.; Zhang, T.; Guan, X.; Dong, Z.; Lan, L.; Yang, S.; Yang, C. Tideglusib and Its Analogues as Inhibitors of Staphylococcus aureus SrtA. J. Med. Chem. 2020, 63, 8442-8457. [CrossRef] [PubMed]

61. Selvaraj, C.; Sivakamavalli, J.; Baskaralingam, V.; Singh, S.K. Virtual screening of LPXTG competitive SrtA inhibitors targeting signal transduction mechanism in Bacillus anthracis: A combined experimental and theoretical study. J. Recept. Signal Transduct. Res. 2014, 34, 221-232. [CrossRef]

62. Reigada, I.; Guarch-Perez, C.; Patel, J.Z.; Riool, M.; Savijoki, K.; Yli-Kauhaluoma, J.; Zaat, S.A.J.; Fallarero, A. Combined Effect of Naturally-Derived Biofilm Inhibitors and Differentiated HL-60 Cells in the Prevention of Staphylococcus aureus Biofilm Formation. Microorganisms 2020, 8, 1757. [CrossRef]

63. Ueda, Y.; Miyazaki, M.; Mashima, K.; Takagi, S.; Hara, S.; Kamimura, H.; Jimi, S. The Effects of Silver Sulfadiazine on MethicillinResistant Staphylococcus aureus Biofilms. Microorganisms 2020, 8, 1551. [CrossRef] [PubMed]

64. Mansson, E.; Tevell, S.; Nilsdotter-Augustinsson, A.; Johannesen, T.B.; Sundqvist, M.; Stegger, M.; Soderquist, B. MethicillinResistant Staphylococcus epidermidis Lineages in the Nasal and Skin Microbiota of Patients Planned for Arthroplasty Surgery. Microorganisms 2021, 9, 265. [CrossRef]

65. Wolters, M.; Frickmann, H.; Christner, M.; Both, A.; Rohde, H.; Oppong, K.; Akenten, C.W.; May, J.; Dekker, D. Molecular Characterization of Staphylococcus aureus Isolated from Chronic Infected Wounds in Rural Ghana. Microorganisms 2020, 8, 2052. [CrossRef] 
66. Zhang, J.; Conly, J.; McClure, J.; Wu, K.; Petri, B.; Barber, D.; Elsayed, S.; Armstrong, G.; Zhang, K. A Murine Skin Infection Model Capable of Differentiating the Dermatopathology of Community-Associated MRSA Strain USA300 from Other MRSA Strains. Microorganisms 2021, 9, 287. [CrossRef] [PubMed]

67. Ikeuchi, K.; Adachi, E.; Sasaki, T.; Suzuki, M.; Lim, L.A.; Saito, M.; Koga, M.; Tsutsumi, T.; Kido, Y.; Uehara, Y.; et al. An Outbreak of USA300 Methicillin-Resistant Staphylococcus aureus among People with HIV in Japan. J. Infect. Dis. 2021, 223, 610-620. [CrossRef] [PubMed]

68. McCaskill, M.L.; Mason, E.O., Jr.; Kaplan, S.L.; Hammerman, W.; Lamberth, L.B.; Hulten, K.G. Increase of the USA300 clone among community-acquired methicillin-susceptible Staphylococcus aureus causing invasive infections. Pediatr. Infect. Dis. J. 2007, 26, 1122-1127. [CrossRef]

69. Ruppitsch, W.; Stoger, A.; Schmid, D.; Fretz, R.; Indra, A.; Allerberger, F.; Witte, W. Occurrence of the USA300 community-acquired Staphylococcus aureus clone in Austria. Eur. Surveill. 2007, 12, E0710251. [CrossRef]

70. Johnson, J.K.; Khoie, T.; Shurland, S.; Kreisel, K.; Stine, O.C.; Roghmann, M. Skin and soft tissue infections caused by methicillinresistant Staphylococcus aureus USA300 clone. Emerg. Infect. Dis. 2007, 13, 1195-1200. [CrossRef] [PubMed]

71. Sifri, C.D.; Park, J.; Helm, G.A.; Stemper, M.E.; Shukla, S.K. Fatal brain abscess due to community-associated methicillin-resistant Staphylococcus aureus strain USA300. Clin. Infect. Dis. 2007, 45, e113-e117. [CrossRef]

72. Popovich, K.J.; Snitkin, E.; Green, S.J.; Aroutcheva, A.; Hayden, M.K.; Hota, B.; Weinstein, R.A. Genomic Epidemiology of USA300 Methicillin-Resistant Staphylococcus aureus in an Urban Community. Clin. Infect. Dis. 2016, 62, 37-44. [CrossRef] [PubMed]

73. Hota, B.; Lyles, R.; Rim, J.; Popovich, K.J.; Rice, T.; Aroutcheva, A.; Weinstein, R.A. Predictors of clinical virulence in communityonset methicillin-resistant Staphylococcus aureus infections: The importance of USA300 and pneumonia. Clin. Infect. Dis. 2011, 53, 757-765. [CrossRef]

74. Wilden, J.J.; Hrincius, E.R.; Niemann, S.; Boergeling, Y.; Löffler, B.; Ludwig, S.; Ehrhardt, C. Impact of Staphylococcus aureus Small Colony Variants on Human Lung Epithelial Cells with Subsequent Influenza Virus Infection. Microorganisms 2020, 8, 1998. [CrossRef] [PubMed]

75. Etter, D.; Jenni, C.; Tasara, T.; Johler, S. Mild Lactic Acid Stress Causes Strain-Dependent Reduction in SEC Protein Levels. Microorganisms 2021, 9, 1014. [CrossRef]

76. Ciupescu, L.; Auvray, F.; Nicorescu, I.M.; Meheut, T.; Ciupescu, V.; Lardeux, A.; Tanasuica, R.; Hennekinne, J. Characterization of Staphylococcus aureus strains and evidence for the involvement of non-classical enterotoxin genes in food poisoning outbreaks. FEMS Microbiol. Lett. 2018. [CrossRef] [PubMed]

77. Chao, G.; Bao, G.; Cao, Y.; Yan, W.; Wang, Y.; Zhang, X.; Zhou, L.; Wu, Y. Prevalence and diversity of enterotoxin genes with genetic background of Staphylococcus aureus isolates from different origins in China. Int. J. Food Microbiol. 2015, 211, 142-147. [CrossRef]

78. Mishra, N.N.; Bayer, A.S.; Baines, S.L.; Hayes, A.S.; Howden, B.P.; Lapitan, C.K.; Lew, C.; Rose, W.E. Cell Membrane Adaptations Mediate $\beta$-Lactam-Induced Resensitization of Daptomycin-Resistant (DAP-R) Staphylococcus aureus In Vitro. Microorganisms 2021, 9, 1028. [CrossRef]

79. Ventola, C.L. The antibiotic resistance crisis: Part 1: Causes and threats. Pharm. Ther. 2015, 40, $277-283$.

80. Van den Driessche, F.; Brackman, G.; Swimberghe, R.; Rigole, P.; Coenye, T. Screening a repurposing library for potentiators of antibiotics against Staphylococcus aureus biofilms. Int. J. Antimicrob. Agents 2017, 49, 315-320. [CrossRef]

81. Bayer, A.S.; Xiong, Y.Q. Redeploying beta-Lactams against Staphylococcus aureus: Repurposing with a Purpose. J. Infect. Dis. 2017, 215, 11-13. [CrossRef]

82. Das, S.; Dasgupta, A.; Chopra, S. Drug repurposing: A new front in the war against Staphylococcus aureus. Future Microbiol. 2016, 11, 1091-1099. [CrossRef]

83. Lozano, C.; Fernandez-Fernandez, R.; Ruiz-Ripa, L.; Gomez, P.; Zarazaga, M.; Torres, C. Human mecC-Carrying MRSA: Clinical Implications and Risk Factors. Microorganisms 2020, 8, 1615. [CrossRef] [PubMed]

84. Gor, V.; Ohniwa, R.L.; Morikawa, K. No Change, No Life? What We Know about Phase Variation in Staphylococcus aureus. Microorganisms 2021, 9, 244. [CrossRef] [PubMed]

85. Kiem, S.; Oh, W.S.; Peck, K.R.; Lee, N.Y.; Lee, J.; Song, J.; Hwang, E.S.; Kim, E.; Cha, C.Y.; Choe, K. Phase variation of biofilm formation in Staphylococcus aureus by IS 256 insertion and its impact on the capacity adhering to polyurethane surface. J. Korean Med. Sci. 2004, 19, 779-782. [CrossRef]

86. Baselga, R.; Albizu, I.; de la Cruz, M.; del Cacho, E.; Barberan, M.; Amorena, B. Phase variation of slime production in Staphylococcus aureus: Implications in colonization and virulence. Infect. Immun. 1993, 61, 4857-4862. [CrossRef]

87. Manasherob, R.; Mooney, J.A.; Lowenberg, D.W.; Bollyky, P.L.; Amanatullah, D.F. Tolerant Small-colony Variants Form Prior to Resistance within a Staphylococcus aureus Biofilm Based on Antibiotic Selective Pressure. Clin. Orthop. Relat. Res. 2021. [CrossRef]

88. Sato, T.; Uno, T.; Kawamura, M.; Fujimura, S. In Vitro Tolerability of Biofilm-Forming Trimethoprim-/Sulfamethoxazole-Resistant Small Colony Variants of Staphylococcus aureus against Various Antimicrobial Agents. Microb. Drug Resist. 2021. [CrossRef] [PubMed]

89. Mirani, Z.A.; Urooj, S.; Khan, M.N.; Khan, A.B.; Shaikh, I.A.; Siddiqui, A. An effective weapon against biofilm consortia and small colony variants of MRSA. Iran J. Basic Med. Sci. 2020, 23, 1494-1498.

90. Stoneham, S.M.; Cantillon, D.M.; Waddell, S.J.; Llewelyn, M.J. Spontaneously Occurring Small-Colony Variants of Staphylococcus aureus Show Enhanced Clearance by THP-1 Macrophages. Front. Microbiol. 2020, 11, 1300. [CrossRef] 
91. Tuchscherr, L.; Loffler, B.; Proctor, R.A. Persistence of Staphylococcus aureus: Multiple Metabolic Pathways Impact the Expression of Virulence Factors in Small-Colony Variants (SCVs). Front. Microbiol. 2020, 11, 1028. [CrossRef]

92. Lee, J.; Zilm, P.S.; Kidd, S.P. Novel Research Models for Staphylococcus aureus Small Colony Variants (SCV) Development: Co-pathogenesis and Growth Rate. Front. Microbiol. 2020, 11, 321. [CrossRef] 